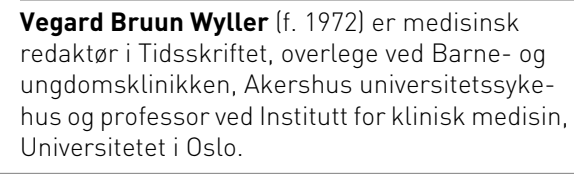

\section{Elefanten i rommet}

For noen år siden hadde jeg ansvaret for en alvorlig syk gutt fra en muslimsk familie. Faren fremsto i perioder som svært frustrert, og ikke bare over sønnens sykdom. En lengre samtale avslørte hvorfor: Han mistrivdes med sykehuset teknologiske ensporethet. Han syntes vi var absurd sekulære, til tider kyniske, i vår holdning til liv og død. Han ønsket å finne Gud på hospitalet - men alt han fant var maskiner.

Sønnen hans døde etter et langt sykeleie. Jeg ble vitne til den etterfølgende religiøse seremonien - en sterk demonstrasjon av kollektiv tro og forsoning med en vond skjebne. Mange familier fremstår som handlingslammet når den største av alle tragedier - et barns død inntreffer. Den tidligere så frustrerte faren hadde derimot en sterk handlingskompetanse, forankret $\mathrm{i}$ hans islamske livssyn.

Hva kan man lære av denne historien? Først og fremst at livssyn og religion betyr noe i medisinsk sammenheng $(1,2)$. Det burde ikke overraske. Både legen og presten interesserer seg for spørsmålet om liv og død, Europas sykehus har sine røtter i middelalderens klostervesen og - kanskje viktigst av alt - å ha et livssyn er en fundamental egenskap ved det å være menneske. Vi søker mening og sammenheng i tilværelsen, spesielt i kritiske livssituasjoner (2). Vi kan tro på ingen, én eller mange guder, men vi kan ikke unngå selve fenomenet tro - vi kan ikke rømme fra spørsmålet om Guds eksistens.

En økende mengde empiriske studier bekrefter tallrike berøringsflater mellom livssyn, religion og medisin. For det første har livssynet helsemessige konsekvenser. De fleste studier antyder at religiøs tro/ praksis har positive virkninger på både mental og kroppslig helse. De underliggende mekanismene kan være både psykologiske (bedre evne til å mestre stress), sosiale (sterke nettverk i religiøse grupperinger) og atferdsmessige (mindre risikoatferd) (3). En fersk undersøkelse dokumenterte positiv sammenheng mellom egenvurdert religiøsitet/ spiritualitet, tykkelse av hjernebarken i visse områder og motstandsdyktighet mot å utvikle depresjon (4). Samtidig kan bestemte religiøse overbevisninger også ha sterke negative helseeffekter, som for eksempel når visse sekter oppfordrer foreldre til syke barn å prioritere «spirituell» fremfor biomedisinsk behandling (5).

For det andre påvirker livssyn sentrale verdivalg. Hva terminale kreftpasienter mener om livsforlengende behandling i livets sluttfase, er i sterk grad forbundet med deres holdning til religiøse spørsmål $(6,7)$. Det samme er tilfellet for foreldre til alvorlig syke nyfødte (8). Og det gjelder selvsagt også leger - hva vi selv tror på, kan påvirke viktige sider ved vår kliniske praksis $(7,9)$. Våre kollegiale diskusjoner om abort, reservasjonsrett, eutanasi og omskjæring er åpenbare eksempler, men vel så viktig er kanskje de mindre gjennomsiktige verdivalgene, som våre beslutninger om behandling av svært gamle pasienter.

For det tredje er livssyn forbundet med særskilte nevrobiologiske fenomener. Åndelige erfaringer hos karmelittnonner gir for eksempel et bestemt aktiveringsmønster i hjernen, vurdert ved funksjonell MR-undersøkelse (10), og det er en assosiasjon mellom bestemte EEG-karakteristika og hvorvidt man opplever religion/spiritualitet som viktig for en selv (11). Det ser med andre ord ut til å være en spesifikk sammenheng mellom religiøs tro og hjernens funksjon (12).

Til tross for denne dokumentasjonen er vi som profesjon merkelig tafatte i møtet med livssynsspørsmål. Det hersker en utstrakt berøringsangst overfor både pasienter og kolleger - Gud er blitt en elefant i rommet, enten det dreier seg om sengerommet eller morgenmøterommet. For de fleste leger er det lettere å snakke med pasientene om deres kjønnsliv enn om deres bønneliv. At det er blitt slik, har sammensatte historiske årsaker. Utviklingen fra opplysningstiden preges av vektlegging av den rent naturvitenskapelige og tekniske siden ved medisinsk fagutøvelse, samtidig som livssyn - spesielt protestantisk kristendom - oppfattes som et rent privat anliggende (3). Men det er uprofesjonelt ikke å identifisere elefanten, spesielt i et samfunn som i stadig større grad preges av livssynsmessig heterogenitet.

Internasjonalt er det økende bevissthet om sammenhengen mellom livssynsspørsmål og medisinsk virksomhet (2). Mange amerikanske universiteter gir medisinstudentene omfattende teoretisk og praktisk skolering i hvordan livssynsspørsmål kan og bør berøres i legepasient-forholdet (13). Det er på tide at vi kommer etter. I første omgang kan vi utfordre hverandre til å identifisere elefanten i rommet. Bare det ville ha hjulpet den frustrerte faren til min muslimske pasient. God påske!

\section{Litteratur}

1. Bråtveit A. Tunge tap med djupe gåter. Tidsskr Nor Legeforen 2014; 134: 740

2. Address RR. Medicine: a partnership of trust and faith. BMJ 2014; 348: g1452.

3. Koenig HG. Religion, spirituality, and health: the research and clinical implications. ISRN Psychiatry 2012. Artikkel-ID 278730. www.hindawi.com/journals/ isrn/2012/278730/ (17.3.2015)

4. Miller L, Bansal R, Wickramaratne P et al. Neuroanatomical correlates of religiosity and spirituality: a study in adults at high and low familial risk for depression. JAMA Psychiatry 2014; 71: 128-35

5. Sinal SH, Cabinum-Foeller E, Socolar R. Religion and medical neglect. South Med J 2008; 101: 703-6.

6. Phelps AC, Maciejewski PK, Nilsson M et al. Religious coping and use of intensive life-prolonging care near death in patients with advanced cancer. JAMA 2009; 301: $1140-7$

7. Peteet JR, Balboni MJ. Spirituality and religion in oncology. CA Cancer J Clin 2013; 63: 280-9

8. Robinson MR, Thiel MM, Backus MM et al. Matters of spirituality at the end of life in the pediatric intensive care unit. Pediatrics 2006; 118: e719-29.

9. Catlin EA, Cadge W, Ecklund EH et al. The spiritual and religious identities, beliefs, and practices of academic pediatricians in the United States. Acad Med 2008; 83: 1146-52.

10. Beauregard M. Paquette V. Neural correlates of a mystical experience in Carmelite nuns. Neurosci Lett 2006; 405: 186-90.

11. Tenke CE, Kayser J, Miller $L$ et al. Neuronal generators of posterior EEG alpha reflect individual differences in prioritizing personal spirituality. Biol Psychol 2013; 94: 426-32.

12. Kapogiannis D, Barbey AK, Su M et al. Cognitive and neural foundations of religious belief. Proc Natl Acad Sci U S A 2009; 106: 4876-81.

13. Puchalski CM, Blatt B, Kogan M et al. Spirituality and health: the development of a field. Acad Med 2014; 89: 10-6. 